
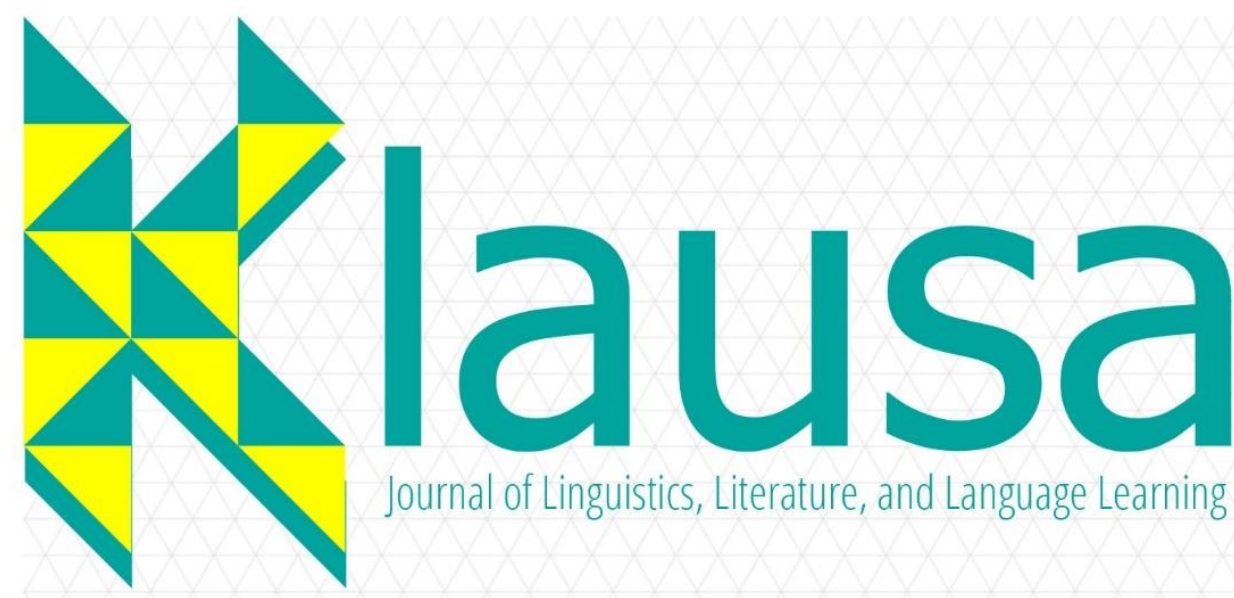

ISNN 2620-9527 Volume 04 Nomor 02

Journal of Linguistics, Literature, and Language Learning

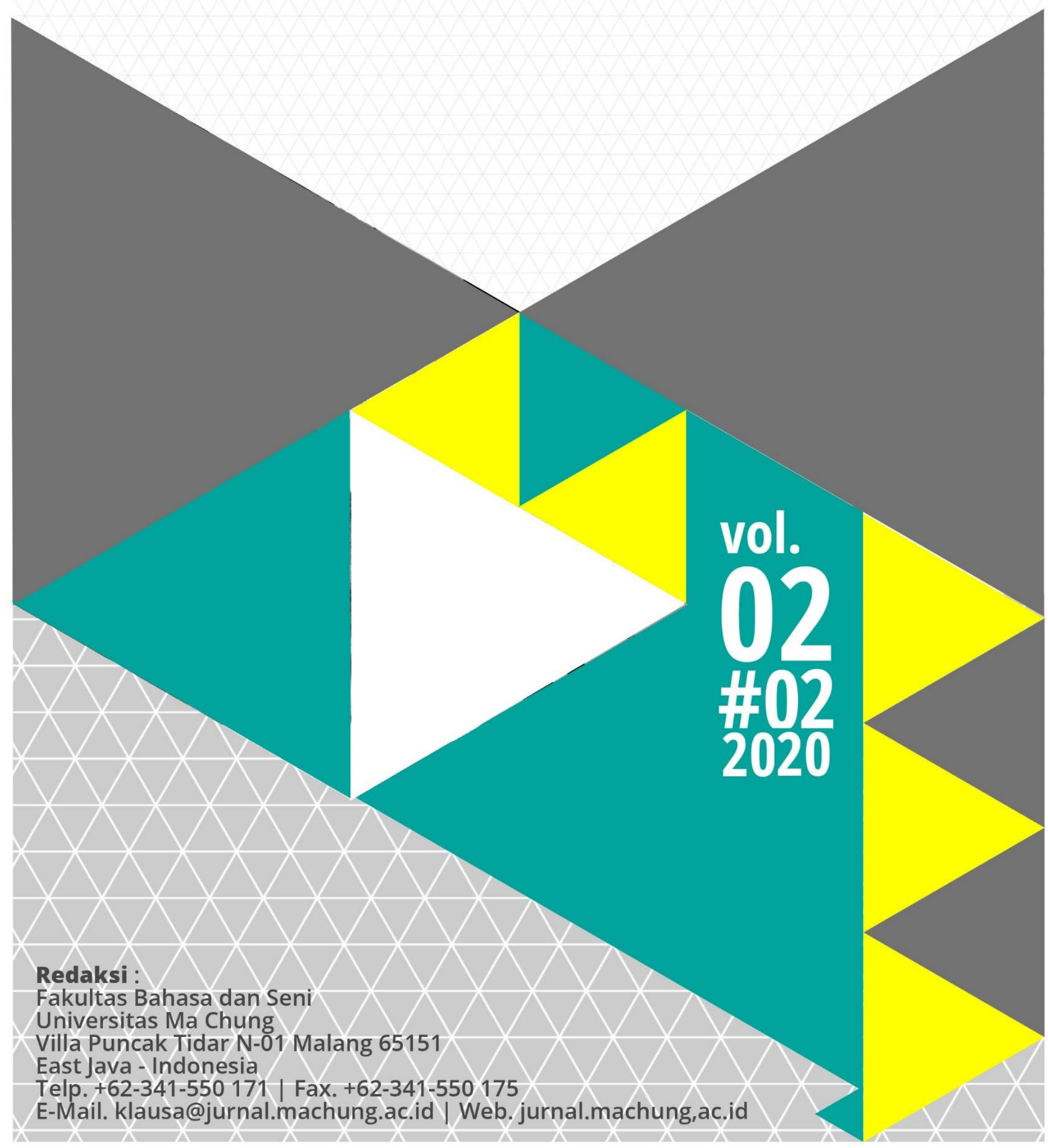


ISSN: $2301-4822(p)$

DOI: $\quad 10.33479 /$ klausa.v4i02

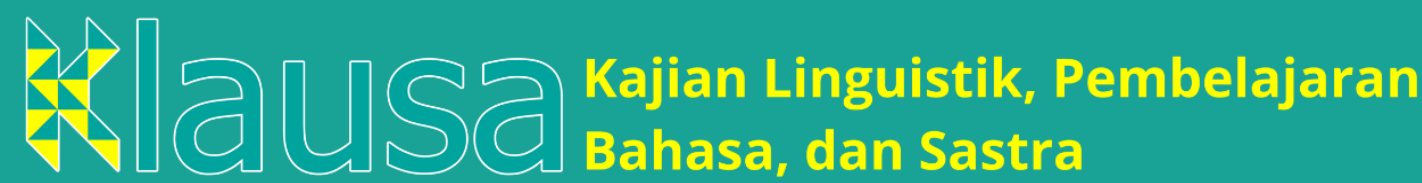

\section{Editorial Team}

\section{Editor-in-Chief}

Journal Manager

Editors

Reviewers

Publisher

Address

Frequency
: $\quad$ Dr. Daniel Ginting

: Wawan Eko Yulianto, Ph.D.

: Prof. Dr. Patrisius I. Djiwandono

Lilis Lestari Wilujeng, M.Hum.

: F.X Dono Sunardi, M.A.

Dhatu Sitaresmi, MTCSOL.

Anggrah Diah Arlinda, MTCSOL.

Yohanna Nirmalasari, S.Pd., M.Pd.

Prof. A. Effendi Kadarisman, Ph.D.

Sisilia Halim, Ph.D.

Dr. Mundi Rahayu

Dr. Ross Wood

Dr. Leticia Araceli Salas Serrano

: Faculty of Language and Arts

Universitsas Ma Chung

: The Faculty of Language and Arts

Ma Chung University

Villa Puncak Tidar N-01 (65151)

Malang, East Java, Indonesia

Email: jurnal.klausa@machung.ac.id

: Twice a year 


\section{CONTENTS}

FOREWORD

iii

(RETRACTED)_PRESUPPOSITION IN THE GUARDIAN NEWS

STORIES: A PRAGMATIC ANALYSIS

Crisnova Katalonika Siahaan ${ }^{1}$, Zia Hisni Mubarak ${ }^{2}$.

FLOUTING MAXIMS IN WHITE HOUSE DOWN

Rebekka Sinaga $^{1}$, Nurma Dhona Handayani ${ }^{2}$ 81

WORD FORMATION IN SHARENA DELON'S INSTAGRAM POSTS: A MORPHOLOGICAL ANALYSIS

Crisnova Katalonika Siahaan¹, Zia Hisni Mubarak² .89

(RETRACTED)_MAXIMS IN JOHN GREEN'S THE FAULT IN OUR STARS: a PRAGMATIC ANALYSIS

Sasmi Saragih $^{1}$, Ambalegin $^{2}$

PENERAPAN CONTENT AND LANGUAGE INTEGRATED LEARNING

(CLIL) PADA PELAJARAN MATEMATIKA DI TINGKAT

PENDIDIKAN DASAR DI INDONESIA

Bebasari Amiroh ${ }^{1}$, Cindy Fortunasari ${ }^{2}$, Daniel Ginting ${ }^{3}$

ANALISIS KUALITAS TERJEMAHAN TEKS BAHASA JEPANG KE

BAHASA INDONESIA DENGAN BING TRANSLATOR

Wisnu Setya Budi ${ }^{1}$, Febi Ariani Saragih ${ }^{2}$

中印姓名比较研究

Anggrah Diah Airlinda ${ }^{1}$

印尼留学生汉语撮口呼韵母偏误分析

Dhatu Sitaresmi ${ }^{1}$ 155 


\title{
WORD FORMATION IN SHARENA DELON'S INSTAGRAM POSTS: A MORPHOLOGICAL ANALYSIS
}

\author{
Crisnova Katalonika Siahaan', Zia Hisni Mubarak ${ }^{2}$ \\ ${ }^{1}$ Putera Batam University, pb161210048@upbatam.ac.id \\ ${ }^{2}$ Putera Batam University, pb161210048@upbatam.ac.id
}

\begin{abstract}
This paper is a qualitative descriptive research which investigates the processes of word formation and their influence to part of speech of the data. The data source in this study is Instagram captions of Sharena Delon. The method of collecting data is by observation. The method of analyzing data is agih and padan method from Sudaryanto. The author uses the theory ofO'Grady which divides word formation process into 10 types, i.e.derivation, compounding, conversion, clipping, blends, backformation, acronym, onomatopoeia, coinage, and inflection. The research uses the theory of Carter \& McCarthy to show the change of part of speech of data. The result of this research shows that based on O'Grady's and Carter \& McCarthy's theory. There are 30 types of word formation process found in Instagram of Sharena Delon. Three types are by derivation process, 2 types by compounding process, 2 types by conversion process, 6 types by clipping process, 6 types by blends process, 2 types by backformation process, 3 types by acronym process, 3 types by onomatopoeia process, 1 type by coinage process, and two types by inflection process. Some data have change of part of speech because of word formation process and some do not.
\end{abstract}

Keywords: morphology; word formation; part of speech.

\section{INTRODUCTION}

Language always develops because people in the society are creative to create the new words and sentences in their communication and writing. For example, when people read or write, they will acquire new expression or style in reading or writing. Malmkjaer (2010) stated that language is an arbitrary system of rules and categories that works by virtue of a 'social contract' tacitly accepted by all speakers. Language is learning social behavior, a skill that is acquired as people grow up in society. To support human's communication in society, people need language to interact and act in the society. Moreover, as well as in economy, education and culture environment, language has an important role there. It is included in international relation. This time, the international language which has been known is English. Because of that, it is an important thing to know the English language. By knowing the English language, people will be more advanced because people can get much important information from abroad. As above discussion, English subject has been taught since Elementary school until in University. Learning English will be easier when people know the science of language which is called as Linguistic. 
Nowadays, as everything becomes more sophisticated, English has become a language that many people speak in their daily communication. In addition, globalization era forces people to develop their skill in many fields especially language. There is no fear that Indonesian people will not be able to speak English fluently. The use of English has entered many fields, like politic, economy, education, art, and entertainment. There are many announcers or hosts in the radio and television program mix their language with English in their conversation. Many writers of novel and short story mix their language with English in their composition or work. Likewise with magazine and newspaper, some journalists mix English to their writing. The English can be the word, phrase, clause, and sentence.

Many kinds of subject study about the language. One subject that has the relation to language is word formation. The word formation process is within the scope of the morphology study. Morphology is the study of word forming. Word formation is the creation of a new lexeme from one or more other lexemes through the application of some morphological process, such as affixation or compounding (Aronoff, 2011). Furthermore, O'Grady (1997) asserts that the system of categories and rules involved in word formation and interpretation makes up a language's morphology. Word formation is the process of forming words, by combining, cutting, summarizing and borrowing from other languages so as to change the form of words from the origin. Furthermore, a new expression or style of language is often written and used in social media "Instagram". The language in writing expression in social may be different to others. It uses the interesting natural language which means the language in the social media is written to convey the feelings to readers. Most of people have two or more languages, namely native language and second language. The language which is usually mastered well by people is their mother tongue or native language. Firstly, people use their mother tongue to communicate to their family and society. This condition causes people to learn another language to make their communication effective. By mastering foreign language, speaker will be able in speaking to all people in the world. People are also creative in creating the new word in order to be cooler. For example: the word KEPO. In this case, KEPO is word that is shortened from four words they are knowing every particular object. It is usually used by Indonesian Instagram user. This morphological process named acronym, because it is formed by taking the initial letters of the words in a phrase and pronouncing them as a word. KEPO is used for curiosity about other people's business. The word class of KEPO is adjective (A).

This research concerned to discuss word formation process and the change of part of speech because of word formation process in the data. This research applies the word formation theory by O'Grady (1997) who divides the types into 10 types. The types are derivation, compounding, conversion, clipping, blends, backformation, acronym, onomatopoeia, coinage, and inflection. To analyze part of speech, the researcher uses the theory of Carter \& McCarthy (2006). This research applies the general part of speech these are noun, verb, adjective, and adverb. The data is taken by Instagram of Sharena Delon.

\section{LITERATURE REVIEW}

\section{Morphology}

According to Kirsten Malmkjaer (2010) morphology is concerned with the forms of words themselves. Carstairs-mccarthy (2002) stated morphology is the area of grammar concerned with the structure of words and with relationships between words involving the 
morphemes that compose them." This word itself consists of two morphemes, morph + ology. Thus, morphology is the science of word forming and also as a part of linguistic knowledge which focuses on how words are formed. The word formation process is within the scope of the morphology study. According to Aronoff (2011) word formation is the creation of a new lexeme from one or more other lexemes through the application of some morphological process, such as affixation or compounding. The word formation process is within the scope of the morphology study. According to Aronoff (2011) word formation is the creation of a new lexeme from one or more other lexemes through the application of some morphological process, such as affixation or compounding. Furthermore, O'Grady (1997) asserts that the system of categories and rules involved in word formation and interpretation makes up a language's morphology. In word formation, there are several patterns and types to analyze it. This research uses the theory by O'Grady (1997) to analyze word formation process in Instagram of Sharena Delon and the theory of Carter \& McCarthy (2006) to analyze part of speech of word formation process in Instagram of Sharena Delon. According to O'Grady (1997) word formation consists of several processes these are derivation, compounding, conversion, clipping, blends, back formation, acronym, onomatopoeia, coinage, and inflection. According to Carter \& McCarthy (2006) the main word classes are noun, verb, adjective, adverb, preposition and conjunction. This research uses the theory by O'Grady (1997) to analyze word formation process in Instagram of Sharena Delon and the theory of Carter \& McCarthy (2006) to analyze the change of part of speech after the word formation process in Instagram of Sharena Delon.

\section{Types of Word Formation Process}

\section{Derivation}

O'Grady (1997) stated derivation forms a word with a meaning and/or category distinct from that of its base through the addition of an affix. Derivation is a process of word formation through the addition of affixes, which can be prefixes and suffixes. The new word produced will have a different meaning from the basic word. The new word will also have a class of words that are different from the basic word. For example: affix -able can change word class of word such as fix (verb) changes into fixable (adjective).

\section{Compounding}

Another common way to build words in English involves compounding, the combination of lexical categories (O'Grady, 1997). Possible examples of compound prepositions include the words into and onto. In these and most other compounds of this type, the final component determines the category of the entire word. Thus, greenhouse is a noun because its rightmost component is an noun, spoonfeed is a verb because feed also belongs to this category, and nationwide is an adjective just as wide is. The morpheme that determines the category of the entire word is called the head.

\section{Conversion}

O'Grady (1997) stated conversion is a process that assigns an already existing word to a new syntactic category. Even though it does not add an affix, conversion is often considered to be a type of derivation because of the change in category and meaning that it brings about. Conversion is the process of changing word classes without changing the original word form. Example: butter the bread and bottle the water. If interpreted literally, butter and bottle are 
nouns. In word formation process the meaning can change into a verb without changing its original form.

\section{Clipping}

Clipping is done to make new words with the same meaning. For example: Gasoline becomes Gas and Professor becomes Prof. It has yielded forms like proff or professor, physed for physical education, poli-sci for political science, and burger for hamburger.

\section{Blends}

O'Grady (1997) stated blends are created from non-morphemic parts of two already existing items. Blending is the process of forming words by combining two words or more by removing certain parts of the old word. Well known examples of blends include brunch from breakfast and lunch, aerobicise from aerobics and exercise, and chunnel from channel and tunnel.

\section{Backformation}

According to O'Grady (1997) backformation is a process that creates a new word by removing a real or supposed affix from another word in the language. Backformation is the process of forming words by separating affixes or the basic words of a word. Backformation is also defined as cutting a part of a word that results the change in the word class from its new form. Simply put, the back formation is a short word made from a longer word. Example: Editor $(\mathrm{N})$, cut or morpheme then become Edit (V).

\section{Acronym}

Acronyms are formed by taking the initial letters of the words in a phrase or title and pronouncing them as a word (O'Grady 1997). This type of word formation is especially common in names of organizations, military, and scientific terminology. Acronyms are abbreviated words in English that are smeared like normal words. The words are pronounced as a short form of the words themselves rather than the full form of the actual words. Examples of acronyms include UNICEF for United Nations International Children's Emergency Fund and AIDS for acquired immune deficiency syndrome.

\section{Onomatopoeia}

O'Grady (1997) stated that all languages have words that have been created to sound like the thing that they name. Since onomatopoeic words are not exact phonetic copies of noises, their form can differ from language to language. Onomatopoeia is one type of rhetorical device where a word written or pronounced is an imitation of a sound effect that comes from things around like the sound of water dripping, the sound of the wind blowing, even the sound of an animal. In short, Onomatopoeia is words that express sound. Examples of such onomatopoeic words in English include buzz, hiss, sizzle, and cuckoo.

\section{Coinage}

Called word manufacture or coinage is especially common in cases where industry requires a new and attractive name for a product (O'Grady 1997). Kodak, Dacron, Orion, and Teflon are examples of product names that are the result of word manufacture. Coinage is a word made from everyday mention of the product name. Communities will tend to mention the 
name on products that are similar and that has function the same as them. Sometimes it is possible to make new words from names.

\section{Inflection}

According to O'Grady (1997) languages have contrasts such as singular versus plural, and past versus present. Languages have contrasts such as singular versus plural, and past versus present. These contrasts are often marked with the help of inflection, morphology used to indicate the grammatical subclass to which it belongs. For example: In number, apple is singular and apples are plural. In tense, work is non-past tense and worked is past tense.

\section{Part of Speech}

A word may be defined as the smallest portions of a sentence which can be pronounced alone and still retain meaning. Some words may contain more than one such element. Each adds a measure of meaning to complete words. Kolln \& Funk, 2008 (as cited in Nopikasari, 2018) stated a word class is a set of words that display the same formal properties, especially their inflections and distribution. This research uses the part of speech theory by Carter \& McCarthy (2006) that sated the main word classes are noun, verb, adjective, adverb, preposition and conjunction which traditionally called as parts of speech. In this research, the researcher will only analyze the four major word classes these are noun, verb, adjective, and adverb. Class Word has a position as a subject, predicate, object, and description, in a sentence. Related to the position in the sentence and its relationship to the function and meaning indicated, words can be categorized into word classes. The word class is divided into 5 types.

\section{Noun}

Noun shows the class and category of things in the world, including people, animals, inanimate objects, places, events, qualities and countries. Nouns are divided into two main classes these are common and proper noun. A common noun is a noun that refers to people or things in general, such as boy, and happiness. A proper noun is a name that identifies a particular person, place, or thing such as Steven and Monday.

\section{Adjective}

An adjective is a word used to describe or limit noun or pronoun. It is also used to modify noun or pronoun for giving extra information about it. When adjectives precede the nouns that qualified, they are said to be attributive. For example: an exciting adventure, a green apple, and a tidy room. The adjective system allows learners to compare one thing with another and grade them on the same adjective qualify, for example: small, smaller, and smallest.

Verb

A verb describes what a person or thing does or what happens. For example, verbs describe: an action, an event, a situation, and change. The basic form of a verb is known as the infinitive. It's often preceded by the word 'to'. For example: to follow and to run.

\section{Adverb}

It can make the meaning of a verb, adjective, or other adverb stronger or weaker, and often appear between the subject and its verb. For example: She nearly lost everything, Can you 
move it carefully? It's fragile, and so on. It is especially important for indicating the time, manner, place, degree and frequency of something.

\section{RESEARCH METHODOLOGY}

Qualitative method used to obtain in-depth data, the data implies. It is the actual meaning of data, data that is certainly a value beyond data that appears. It has been said that the method of this of study emphasize the research's own as an instrument. To be an instrument, the researcher should have a provision theory and insight. Thus, to ask, analyze, photograph, and construct the social situation under study become more apparent and meaningful. This research uses the qualitative descriptive method which collects the data by observation in Instagram of Sharena Delon. Bogdan and Taylor (as cited in Meleong, 2002) stated qualitative research method is defined as a research procedure which produces descriptive data in the form of words written or spoken of the person. Qualitative research is a method of the research by describing an analysis of the data. According to Arikunto (2010) descriptive research is the study intended to investigate the situation, condition, circumstances, events, and other activities, and the result presented in the form of the research report. This research will be done by non-participant observation method without guide and the researcher has a role as main observer in observing language object. The researcher used distributional method and referential method by Sudaryanto (2015). The writer used distributional method to select the data in the Instagram to classifying the data into the kinds of word formation process and to analyze the data the writer used distributional method. After gaining and collecting the data, the researcher takes the next step that is analyzing the data. In qualitative research, data analysis begins when the observation is started. It is on-going activity throughout the whole investigation. According to Sudaryanto (2015) there are two methods to analyze data, they are agih and padan method. In this research, agih method is used to analyze the word forming process, while padan method is used to analyze the meaning of the word. The technique of the agih method used in analyzing data is the Ultimate Constituent Analysis. This technique is intended to disentangle a certain lingual unit of its smallest elements. After analyzing the data, the researcher will present the result. There are two methods to present the data analysis (Sudaryanto, 1993, p. 144). The methods are formal and informal method. Formal method is method of presenting data by using symbols and mark. Informal method is method of presenting data by using natural language. The result of this research will be presented informally, because the result will be in the form of words. In this research, the verb is abbreviated with letter (V), adjective is abbreviated with letters (Adj), noun is abbreviated with letter $(\mathrm{N})$, and adverb is abbreviated with letters (Adv). The researcher also finds the data in the form of phrase. The noun phrase is abbreviated with letters (NP) and adjective phrase is abbreviated with letters (AdjP). The data analyzed is about the types of word formation processes and the change of part of speech after the process.

\section{RESULT AND DISSCUSSION}

\section{Derivation}

Derivation is a process of word formation through the addition of affixes, which can be prefixes and suffixes. The researcher has found the data of derivation these are: 


\section{Data 1: Hydropapa}

The word of hydropapa comes from word hydro and papa. The hydro (prefix) means the water or something relating to the water and papa $(\mathrm{N})$ means a person who has a role as a father in a family. Hydropapa is a nutrient that is water intended for a father. The word formation process of the word hydro and papa becomes hydropapa is derivation, because there is an adding of prefix hydro- to the word. The morphological process of hydro and papa becoming hydropapa changes the meaning, but part of speech of the word remains as a noun $(\mathrm{N})$, because the word referring to the shape of an object. It is included into common, countable, and concrete noun, because it denotes the general thing, can be counted, and it has the appearance.

\section{Data 2: Selfie}

The base word of selfie is self. Self has the meaning as a person personality or character that makes them different from others. Selfie has meaning as the activity of taking photos done by as a photo taking activity carried out by the self typically with a smartphone or a webcam. The word class of the word self is noun $(\mathrm{N})$. The word formation process of the word self to $\underline{\text { selfie }}$ is derivation, because there is an adding of suffix -ie that is self and -ie becomes selfie. The morphological process from the word self to selfie changes the meaning, but part of speech of the word self to selfie does not change or remains as a noun, because the word selfie describes the noun or person. Hence, part of speech of the word selfie is noun $(\mathrm{N})$, the same as the word self. This word is included into common, countable, and concrete noun, because it denotes the general thing, can be counted, and this is tangible.

\section{Data 3: Instagrammable}

The base word of the word instagrammable is Instagram $(\mathrm{N})$. The word class of Instagram is noun (N). Instagram is social media that is widely used and liked by almost all people both young and old people because the model is not complicated and as a place to upload photos, videos and live broadcasts. Meanwhile, instagrammable is something cool and appropriate appears on social media Instagram and interestingly uploaded to Instagram. The word formation process of the word Instagram becomes instagrammable named derivation, because there is an adding of suffix -able that is Instagram + able becomes instagrammable. The morphological process of the word Instagram becomes instagrammable changes the meaning and also part of speech of the word instagrammable becomes adjective (Adj), because suffix -able is an adjective suffix. This word is included into gradable adjective, because it is something that can be graded.

\section{Compounding}

Compounding is the combination of lexical categories. In these and most other compounds of this type, the final component determines the category of the entire word. The researcher has found the data of compounding process these are:

Data 1: Waterbaby 
Waterbaby comes from two words these are water $(\mathrm{N})$ and baby $(\mathrm{N})$. They are compounded to make a new word with the different meaning. Water is liquid chemical substance and baby is a newborn child and still very young. Waterbaby means the babies whose birth process is done in water which aims to simplify the birth process, as well as relieve pain in the mother and is done naturally. The process of the forming of the word water and baby becomes waterbaby named as compounding, because there is a process of forming new words by combining two words and producing the new meaning. The morphological process of the word water and baby becomes waterbaby changes the meaning and part of speech of this word remains noun $(\mathrm{N})$, because the word refers to an object. It is included into common, countable, and concrete noun, because it denotes the general thing, can be counted, and it has the form.

\section{Data 2: Breast-feeding}

Breast-feeding comes from two words these are breast $(\mathrm{N})$ and feeding $(\mathrm{N})$. They are compounded to produce a new word with the different meaning. Breast function as a food source for babies and feeding is an activity in giving the food or nutrient. Breast-feeding is milking activity for infants or young children from breastfeeding woman. The process of the forming of the word breast and feeding becomes breast-feeding called as compounding, because they form the new word by combining two or more words which the meaning of the new word is far different from the words that form it or merging words as a whole. The morphological process of the word breast and feeding becomes breast-feeding changes the meaning, but part of speech of the word breast-feeding still as noun $(\mathrm{N})$ because it identifies the thing. It is included into common, countable, and concrete noun, because it denotes the general thing, can be counted, and this is the noun that can be seen.

\section{Conversion}

Conversion is the process of changing word classes without changing the original word form. The researcher has found the data of conversion these are:

\section{Data 1: Post}

Post has more than one function in language, can be as a verb (V) and noun $(\mathrm{N})$ in language. If it is as a verb (V), the meaning of post is displaying or uploading text, images, and videos on an Instagram. It is included into lexical verb, because it denotes the type of event. If it is as a noun $(\mathrm{N})$, post is pictures, text, videos uploaded on Instagram. It is included into common, countable, and concrete noun, because it denotes the general thing, can be counted, and it has a form. The word formation process of the word post called as conversion, because this process changes the part of speech and meaning of the existing root without producing any changes in pronunciation or spelling and without adding any affixes. The morphological process of the word post changes the meaning it produces in accordance with its function in the language as well as its word class. Each part of speech has a specific meaning and purpose.

\section{Data 2: Spot}

Spot has two functions in language, can be as a verb (V) and noun (N) in language. If it is as a verb $(\mathrm{V})$, the meaning of spot is to look, searching, and finding something. It is 
included into lexical verb, because it denotes the type of action. If it is as a noun (N), the spot is the dot, place, speck, and stain. It is included into common, countable, and concrete noun, because it denotes the general thing, can be counted, and this is tangible. The word formation process of the word spot named as conversion, because the meaning and word class of spot can change without changing the original form of the word and there is nothing the adding of any affixes to the word. The morphological process of the word spot changes the meaning that it brings about in accordance with its function in the language as well as its word class. Each part of speech has a specific meaning and purpose.

\section{Clipping}

Clipping is done to make new words, but with the same meaning. The researcher has found the data of clipping these are:

\section{Data 1: Bio}

The word bio comes from the word biography. If the word biography is shortened by deleting two syllables these are gra and phy, it becomes bio. The meaning of biography is stories or information about someone that is usually displayed in the upper right of someone's Instagram account. The morphological process of the word biography becomes bio named clipping, because this word is shortened and some syllables are reduced from a longer word to make a new word. The word class of biography is noun $(\mathrm{N})$, because it refers to the thing; it can be seen from the noun suffix -graphy. It is included into common and countable noun, because it denotes the general thing and it is something that can be counted and it is a concrete noun. This morphological process does not change its meaning a well as part of speech of the word. Therefore, part of speech of bio is noun $(\mathrm{N})$, the same as the word biography.

\section{Data 2: Pro}

The word pro comes from the word professional. If the word professional is shortened by reducing three syllables these are $\underline{f e s}, \underline{\text { sion, }}$ and $\underline{\text { al, }}$ it becomes pro. The meaning of professional is high ability possessed by someone with a particular field. The morphological process from the word professional to pro called as clipping, because some syllables are removed from a longer word to create a new word. The word class of professional is adjective (Adj); it can be seen from the adjective suffix -al in the word professional, because suffix -al identifies the adjective. It is included into gradable adjective, because it can be graded. This morphological process does not change its meaning; it means they have the same meaning and also part of speech of the word. Therefore, part of speech of pro is adjective (Adj), the same as the word professional.

\section{Data 3: App}

The word app comes from the word application. If three syllables $\underline{\underline{i}}, \underline{\mathrm{ca}}$, and tion of the word application are dropped, it becomes app. Application is a software or computer programs that operate on certain systems that are created and developed to carry out certain commands with specific objectives. The morphological process from the word application becomes app is clipping, because there is the reducing of some syllables from a longer word in order to create 
a new word. The word class of application is noun $(\mathrm{N})$; it can be seen from the noun suffix ation which identifies the noun in the word application. It is included into common and countable noun, because it identifies the general thing and can be counted and it is also a concrete noun. This morphological process does not change its meaning as well as part of speech of the word. Therefore, part of speech of app is noun $(\mathrm{N})$, the same as the word application.

\section{Data 4: Lil}

Lil comes from the word little. One syllable of the word little is reduced and shortened, it becomes lil. This word is often used by social media user, like in saying lil brother or lil sister. The meaning of little is the something that is not much or small or to say the younger. The morphological process from the word little becomes lil named clipping, because one syllable is reduced from a longer word to produce a new word. The word class of little is an adjective (Adj), because this word is able to explain or change noun or pronoun to be more specific. This word is included into gradable adjective, because it can be graded. This morphological process does not change the meaning as well all its part of speech. Therefore, part of speech of the word lil is adjective (Adj), the same as the word little.

\section{Data 5: Burger}

Burger comes from the word hamburger. One syllable ham in the word hamburger is removed or dropped, it becomes burger. Hamburger is a type of food in the form of round bread sliced in half and filled with patty in the middle which is usually taken from meat, then vegetables in the form of lettuce, tomatoes and onions. The morphological process of the word hamburger becomes burger called clipping, because one syllable is omitted from a longer word in order to produce a new word. The word class of hamburger is noun $(\mathrm{N})$, because it refers to the thing or object. It is included into common noun and countable noun, because it identifies the general thing and can be counted and it is also a concrete noun. This morphological process does not change its meaning and part of speech of the word. Therefore, part of speech of the word burger is noun $(\mathrm{N})$, the same as the word hamburger.

\section{Data 6: Gym}

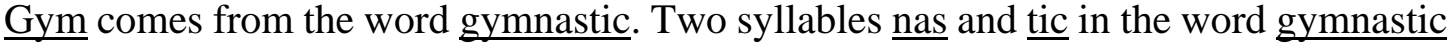
are dropped, it becomes gym. Gymnastic has the meaning as the means to carry out physical activities in sports. The morphological process of the word gymnastic becomes gym is called as clipping, because there is the removing of two syllables from a longer word in order to produce a new word. The word class of gymnastic is noun $(\mathrm{N})$, because it denotes to the thing or object. It is included into common noun and countable noun, and concrete noun, because it identifies the general thing, can be counted, and has the physical object. The morphological process of the word gymnastic becomes gym does not change its meaning as well as part of speech of the word. Therefore, part of speech of the word gym is noun $(\mathrm{N})$, the same as the word gymnastic. 


\section{Blends}

Blending is the process of forming words by combining two words or more by removing certain parts of the old word before being combined into a new word. The researcher has found the data of blends these are:

\section{Data 1: Busui}

Busui is blended word by phrase ibu menyusui. This word is usually used by Indonesian people. Ibu $(\mathrm{N})$ is someone who gives birth to a child, while menyusui (V) is the activity of feeding a baby. If these two words are combined, busui means a mother who is breastfeeding her baby or small child. The word class of the phrase ibu menyusui is noun phrase (NP), because it refers to the object. The morphological process of the words $i b u$ and menyusui become busui named blends, because two words are combined becomes one word by removing certain syllables of the words before being combined into a new word. It is included into common noun and countable noun, because it is the general thing and can be counted and it is also a concrete noun. The morphological process of the word busui does not change the meaning and part of speech of the word; only shortens the words. In conclusion, part of speech of

the word busui is noun $(\mathrm{N})$, the same as the phrase ibu menyusui.

\section{Data 2: Modus}

Modus is blended word by phrase modal dusta. This word is usually used by Indonesian society. Modal (N) means something owned or an asset. Dusta $(\mathrm{N})$ means lie or falsehood. If they are combined, modus is the activity of lying to someone, because it has certain purpose and intention. The word class of the phrase modal dusta is noun phase (NP). The morphological process of the words modal and dusta become modus called blends, because there is the combination of two words become one word by removing certain syllable of the words before being combined into a new word. The word class of modus is noun $(\mathrm{N})$, because it denotes the abstract thing. It is included into common and countable noun, because it is the general thing can be counted and it is an abstract noun. The morphological process of the word modus does not change the meaning and part of speech of the word; only shortens the words. In conclusion, part of speech of the word modus is noun (N), the same as the phrase modal dusta.

\section{Data 3: Jadul}

Jadul is blended word by phrase jaman dulu. It is usually used by Indonesian people. Jaman (N) means the era or time, while dulu (Adj) means the past or the time has passed. It these two words are combined, jadul means the objects that are old or have not been produced anymore and are no longer used today. The part of speech of the phrase jaman dulu is adjective phrase (AdjP). The morphological process of the words jaman and dulu become jadul named blends, because two words are combined becomes one word by removing certain syllable of the words before being combined into a new word. The word class of jadul is adjective (Adj), because it describes the quality of the noun. Jadul is included into gradable adjective, because it is something which can be graded. The morphological process of the word jadul does not change the meaning; only shortens the words, but it produces the new part of speech that is 
adjective (Adj). In conclusion, part of speech of the word jadul is adjective (Adj), the same as the phrase jaman dulu.

\section{Data 4: Vlog}

Vlog is blended word by phrase video blog. Video $(\mathrm{N})$ is an electronic technology of a moving image and blog $(\mathrm{N})$ is an online journal that contains the latest posting information. If they are combined, vlog is the note or information in the form of blogging activities using video or moving image media. The part of speech of the phrase video blog is noun phrase (NP). The morphological process of the words video and blog become vlog is blends, because there is a union of two or more parts of the word to form a new word by reducing the certain syllable of each word. The word class of vlog is noun $(\mathrm{N})$, because it denotes class of the thing. It is included into common, countable and concrete noun, because it is the general thing, can be counted, and it has the form. The morphological process of the word vlog does not change the meaning and part of speech of this word remains the noun; only shortens the words. In conclusion, part of speech of the word vlog is noun $(\mathrm{N})$, the same as the phrase video blog.

\section{Data 5: Ongkir}

Ongkir is blended word by phrase ongkos kirim. It is usually used by Indonesian people. Ongkos (N) means shipping or delivery fees and kirim (V) means delivery actions carried out by intermediaries. If these words are combined, ongkir has the meaning as shipping costs in buying and selling transactions. The part of speech of the phrase ongkos kirim is noun phrase (NP). The morphological process of the words ongkos and kirim become ongkir named as blends, because there is a combination of two parts of the word to form a new word by omitting certain syllable of each word. The word class of ongkir is noun $(\mathrm{N})$, because it denotes an object. It is included into common, countable, and concrete noun, because it is the general thing, can be counted, and it has the form. The morphological process of the word ongkir does not change the meaning; only shortens the words, but it makes the new part of speech that is noun $(\mathrm{N})$.

\section{Data 6: Mager}

Mager is blended word by phrase malas gerak. It is usually used by Indonesian people. Malas (Adj) has the meaning as a feeling in which someone is reluctant to do something or there is no desire to do it and gerak $(\mathrm{N})$ has the meaning as the motion or action. If these two words are combined, mager has the meaning as the nature or state of being lazy to move and do any activity. The part of speech of the phrase malas gerak is adjective phrase (AdjP). The morphological process of the words malas and gerak become mager named as blends, because there is a merging of two parts of the word to form a new word by dropping the syllable of each word. This morphological process does not change the meaning and part of speech of this word remains the adjective. The word class of the word mager is adjective (AdjP), because it describes the state of the noun or pronoun. It is included into gradable adjective, because it can be graded. The morphological process of the word mager does not change the meaning; only shortens the words, but it creates the new part of speech that is adjective (Adj). 


\section{Backformation}

Backformation is the process of forming words by separating affixes or the basic words of a word. The researcher has found the data of backformation these are:

\section{Data 1: Photogra्चेpher Photograph}

If the suffix -er in the word of photographer is removed, the word will change becoming photograph. The word photographer comes from the base word photograph to show the different noun. The word class of photograph is verb (V) and noun (N), while the word class of the word photographer is noun $(\mathrm{N})$. Photograph is a picture or images obtained from photography (N) and record photographic films (V), while photographer is someone who takes photos professionally. The words photographer and photograph are included into common, countable, and concrete noun, because they denote the general thing, can be counted, and they have the shape. The word photograph is included into lexical verb, because it denotes the type of action. This process called as backformation process, because the process creates a new word by removing a real affix from the word photographer. The morphological process of the word photographer becomes photograph changes the meaning as well as part of speech in accordance with its function in the language.

\section{Data 2: Receptionist Reception}

If the suffix -ist in the word receptionist is cut, the word will change becoming reception. The word receptionist comes from the base word reception. The word class of reception is noun $(\mathrm{N})$ as well as the word receptionist is noun $(\mathrm{N})$. The words receptionist and reception are included into common and countable noun, because they are the general things and can be counted. Receptionist is the concrete noun, while reception is the abstract noun. This morphological process named as backformation process, because it is the process of forming words by separating affixes or the basic words of a word and simply put, it is a short word made from a longer word. The morphological process of the word receptionist becomes reception changes the meaning, but not part of speech. In conclusion, the part of speech of them is still the same.

\section{Acronym}

The words are pronounced as a short form of the words themselves rather than the full form of the actual words. The researcher has found the data of acronyms these are:

\section{Data 1: ASI}

$A S I$ is word that is shortened from three words these are air susu ibu. This word is used by Indonesian people. Air $(\mathrm{N})$ means the liquid form, susu $(\mathrm{N})$ is white nutritious liquid produced by the mammary glands, and $i b u(\mathrm{~N})$ is someone who gives a birth to a baby. ASI is the milk that is produced by mother for consumption by infants and is the main source of nutrition for infants. The part of speech of the phrase air susu ibu is noun phrase (NP). The morphological process of the phrase air susu ibu becomes ASI named as acronym, because it is formed by taking the initial letters of the words in a phrase and pronouncing them as a word. This morphological process of the word ASI does not change the meaning as well as its part of 
speech. In conclusion, part of speech of the word ASI is noun $(\mathrm{N})$, the same as the phrase air susu ibu. It is included into common, countable, and concrete noun, because it is general thing, can be counted, and it is tangible.

\section{Data 2: $B P O M$}

$B P O M$ is word that is shortened from four words these are badan pengawas obat dan makanan. It is used by Indonesian society. The word badan $(\mathrm{N})$ means agency or institution, pengawas $(\mathrm{N})$ means the people who control and look after something, obat $(\mathrm{N})$ means the substances used to cure diseases, and makanan $(\mathrm{N})$ means substances eaten by living things to get nutrients. In conclusion, BPOM is an institution in which is tasked with overseeing the distribution of medicines and food. The part of speech of the phrase badan pengawas obat dan makanan is noun phrase (NP). The morphological process of the phrase badan pengawas obat dan makanan becomes BPOM named as acronym, because it is formed by taking the initial letters of the words in a phrase and pronounced as a word as usual. The word class of BPOM is noun $(\mathrm{N})$. This morphological process does not change the meaning as well as its part of speech. Therefore, part of speech of the word BPOM is noun $(\mathrm{N})$, the same as the phrase badan pengawas obat dan makanan. It is included into common, countable, and concrete noun, because it is general thing, can be counted, and it has form.

\section{Data 3: SIM}

SIM is word that is shortened from three words these are surat izin mengemudi. It is used by Indonesian people. The word surat $(\mathrm{N})$ has the meaning as means of communication in the form of written information, izin $(\mathrm{N})$ is the approval or allow, and mengemudi $(\mathrm{V})$ is carrying and controlling vehicles. In conclusion, SIM is a proof of registration and identification provided by the Indonesian National Police to someone who has fulfilled administrative requirements, is physically and mentally healthy, understands traffic rules and is skilled at driving a motorized vehicle. The part of speech of the phrase surat izin mengemudi is noun phrase (NP). The morphological process of the phrase surat izin mengemudi becomes SIM is acronym, because it is formed by taking the initial letters of the words in a phrase and it is pronounced like a word in general. This morphological process does not change the meaning as well as part of speech of the word. Hence, part of speech of the word SIM is noun $(\mathrm{N})$, the same as the phrase surat izin mengemudi. It is included into common, countable, and concrete noun, because it is general thing, can be counted, and it has form.

\section{Onomatopoeia}

Onomatopoeia is words that express sound. The researcher has found the data of onomatopoeia these are:

\section{Data 1: Ngakak}

Ngakak is created by the sound of laughing. It is usually used by Indonesian people. It can happen if there is something funny. It imitates the natural sound of the thing that is in laughing. Ngakak has the meaning as the term of roaring with laughter. The morphological process of the word ngakak named as onomatopoeia, because the word is produced by imitation 
of the natural sounds of a thing. The word class of ngakak is verb (V) in language, because it denotes the action of noun or pronoun. It is included into lexical verb. This morphological process does not change the meaning as well as part of speech of the word. In conclusion, the word ngakak will be a verb (V) in language.

\section{Data 2: Pukpuk}

Pukpuk is created by the sound of hitting something. It is usually used by Indonesian people. The term pukpuk may come from the word "menepuk-nepuk". It imitates the natural sound of the thing that is in hitting something. This word has the meaning as giving feelings of pity to people or something that is sad, broken hearted, and upset which is basically an expression of pity with the touch of a hand and sounds pukpuk. The morphological process of this word named onomatopoeia, because the word is produced by imitation of the natural sounds of a thing. The word class of pukpuk is verb (V), because it identifies the type of event or action. This word is included into lexical verb. This morphological process does not change the meaning as well as part of speech of the word. In conclusion, the word pukpuk will be a verb (V) in language.

\section{Data 3: Mengaum}

Mengaum is created by the sound in the roar of tigers and lions. It is usually used by Indonesian people. It imitates the natural sound of animal's roar. It has the meaning as to roar like a tiger and lion or make a roar. This morphological process called as onomatopoeia, because the word is produced by imitation of the natural sounds of a thing. The word class of mengaum is verb $(\mathrm{V})$, because it indicates the type of state or action. It is included into lexical verb. This morphological process does not change the meaning as well as part of speech of the word. In conclusion, the word mengaum will be a verb (V) in language.

\section{Coinage}

Coinage is a word made from everyday mention of the product name. The researcher has found the data of coinage these are:

\section{Data 1: IPhone}

IPhone is the brand name of Apple smartphone. It connects computers, iPods, digital cameras and cellphones into one device with a touch screen interface. It has the same function

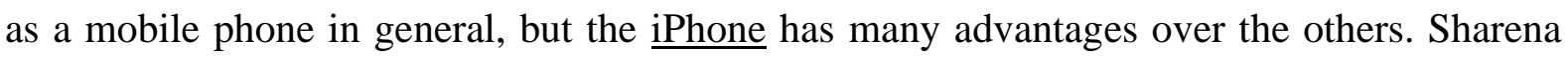

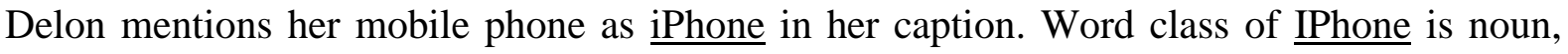
because it represents the thing and object. It is included into proper, countable, and concrete noun, because is the specific thing, can be counted, and has the form or shape. The morphological process of the word IPhone is coinage, because the Instagram user uses the brand of product in mentioning her personal belongings rather than the name of the thing, like mobile phone. This morphological process does not change the meaning of the word as well as part of speech of the word. In conclusion, part of speech of this word is always noun $(\mathrm{N})$. 


\section{Inflection}

In the case of English noun, inflection marks the plural subclass by adding the affix -s and in the case of verbs, inflection can mark a distinction between the past and non-past subclasses by adding the suffix -ed to indicate the past tense. The researcher has found the data of inflection these are:

\section{Data 1: Stories}

The word stories come from the base word of story. Both have the same meaning, but differ in subclass. Story has the meaning as the event that unfolds how things happen. The word formation process of the word story becomes stories is inflection, because there is the mark of plural subclass by adding the affix $-\mathrm{s}$ in the word story that is story $+\mathrm{s}$ becomes stories. The word story is singular subclass, while the word stories is plural subclass. Part of speech of the word story is noun $(\mathrm{N})$, because it indicates the object or thing. This word is included into common, countable, and abstract noun, because it is the general thing, can be counted, but cannot be seen and touched. This morphological process does not change the meaning and also part of speech of the word. It just changes the subclass of the word from singular to plural. In conclusion, part of speech of the word story and stories are noun $(\mathrm{N})$.

\section{Data 2: Changed}

The word changed comes from the base word change. Both have the same meaning, but differ in subclass. Change has the meaning as to make the transformation or to be different than before. Changed is the past form of the word change. The word formation process of the word change becomes changed called as inflection, because there is the mark of a distinction between the past and non-past subclasses by adding the suffix -ed to the word change. The word change is present subclass, while changed is the past subclass. Part of speech of the word change is verb $(\mathrm{V})$, because it indicates type of action or event. It is included into lexical verb. The morphological process of this word does not change the meaning and also part of speech of the word. It just changes the subclass of the word from present to past. In conclusion, part of speech of the word change and changed are verb (V).

\section{CONCLUSION}

The researcher has done the research about an analysis of word formation process in Instagram of Sharena Delon: morphological approach. The process is based on the theory of O'Grady (1997). They are derivation, compounding, conversion, clipping, blends, backformation, acronyms, onomatopoeia, coinage, and inflection. This research also applies the theory by Carter \& McCarthy (2006) to analyze part of speech of the data. Part of speech consists of noun, verb, adjective, and adverb.

There are 30 types of word formation process found that occur in Instagram of Sharena Delon. 3 types by derivation process, 2 types by compounding process, 2 types by conversion process, 6 types by clipping process, 6 types by blends process, 2 types by backformation process, 3 types by acronym process, 3 types by onomatopoeia process, 1 type by coinage process, and two types by inflection process. Some data have the change of part of speech 
because of word formation process and some data do not. Based on the data that researcher found, it can be seen that the clipping and blends process are mostly occur in Instagram of Sharena Delon. It shows that people like to shorten the longer word for becoming one new word in the use of their daily language. Coinage process is the least process used in Instagram of Sharena Delon. It indicates that people do not often use branded products to name goods. 


\section{REFERENCES}

Arikunto, S. (2010). Prosedur penelitian “suatu pendekatan praktis.” Jakarta: Rineka Cipta. Aronoff, M. (2011). What is morphology? (2nd ed.). West-Sussex: Wiley-Blackwell.

Carstairs-mccarthy, A. (2002). An introduction to english morphology: words and their structure. (H. Giegerich, Ed.). Edinburgh: Edinburgh University Press.

Carter, R., \& McCarthy, M. (2006). Cambridge grammar of english (1st ed.). Cambridge: Cambridge University Press.

Malmkjaer, K. (2010). The routledge linguistics (3rd ed.). London and New York: Routledge Taylor and Francis Group.

Meleong, L. J. (2002). Metodologi penelitian kualitatif. Bandung: Remaja Rosdakarya.

Nopikasari, N. (2018). Analysis word classes in selected poems by allan. Journal of English Education and Applied Linguistics, 7(2), 1-14.

O’Grady, W. (1997). Contemporary linguistics. (W. O’Grady, Ed.) (3rd ed.). New York: Douglas Bell.

Sudaryanto. (1993). Metode dan aneka teknik analisis bahasa. Yogyakarta: Duta Wacana University Press.

Sudaryanto. (2015). Metode dan aneka teknik analisis bahasa. Yogyakarta: Sanata Dharma University Press. 